\title{
PELATIHAN PELATIH SEPAKBOLA PEMUDA KARANG TARUNA JAYA PERTALA DESA CIKONENG KECAMATAN SUKAHAJI KABUPATEN MAJALENGKA
}

\author{
Indrayogi \\ Universitas Majalengka, Indonesia \\ indrayogi13@gmail.com
}

\begin{abstract}
Football is the sport most favored by all groups, including in Cikoneng village where many children like the sport of football, but there is still a lack of special coaching and training, so an understanding of how and techniques to play and improve skills need to be considered. This requires youth to improve thinking skills, non-academic (soft skills) and academic / technical (hard skills) as well as to be competitive (competitive). Based on the results of pre-research, the current condition, Karang Taruna Putra Jaya Pertala Cikoneng Village does not have a football coach or coach and children are still doing their own training without any guidance or coach. This PKM program aims to provide football training for Karang Taruna Jaya Pertala Cikoneng Village for early childhood, U-12, and U-15. Where the main target is the acquisition of skills to train and nurture children to play football as needed so that it can be used in daily training and also when facing championships. The target output expected from this service is an accredited national journal. In the training process, partners will be provided with modules based on the need analysis process, football training for grassroots, presenting expert coaches who are nationally licensed, involving other supporters in training and videos about football training. Skilled training (real context) is expected to be the main asset for members of Karang Taruna Putra Jaya Pertala who are competitive and can apply it as a trainer / coach, assistant coach, coach, etc. So that they become individuals who have broader insight and are able to socialize with the wider community in the field of football.
\end{abstract}

Keywords: Youth organization; Football Coach

\begin{abstract}
Abstrak
Sepakbola merupakan olahraga yang paling digemari oleh semua kalangan, termasuk di desa Cikoneng yang banyak anak-anak menyukai olahraga sepakbola, namun masih kurang pembinaan dan pelatihan yang khusus, sehingga pemahaman akan cara dan teknik bermain serta meningkatkan skill perlu diperhatikan. Hal ini menuntut para pemuda untuk meningkatkan keterampilan berfikir, non-academic (softskill) dan academic/teknis (hardskill) serta berdaya saing (competitive). Berdasarkan hasil pre-research, kondisi saat ini, Karang Taruna Putra Jaya Pertala Desa Cikoneng belum mempunyai Pembina atau pelatih sepakbola dan anak-anak masih melakukan latihan sendiri tanpa ada bimbingan atau pelatih. Program PKM ini bertujuan untuk memberikan pelatihan sepakbola untuk Karang Taruna Jaya Pertala Desa Cikoneng bagi anak usia dini, U-12, dan U-15. Dimana target utamanya adalah pemerolehan keterampilan melatih dan membina anak-anak untuk bermain sepakbola sesuai kebutuhan sehingga dapat digunakan dalam latihan sehari-hari dan juga ketika menghadapi kejuaraan. Target luaran yang diharapkan dari pengabdian ini yaitu jurnal nasional terakreditasi. Pada proses pelatihan, mitra akan dibekali modul yang dibuat berdasarkan proses need analysis, pelatihan sepakbola untuk grassroot, menghadirkan pakar pelatih yang berlisensi nasional, melibatkan pendukung lain dalam melatih serta video-video mengenai pelatihan sepakbola. Terampil melatih (real context) diharapkan menjadi modal utama bagi anggota Karang Taruna Putra Jaya Pertala yang berdaya saing dan dapat mengaplikasikannya sebagai pelatih/Coach, assiten pelatih, pembina, dll. Sehingga mereka menjadi pribadi yang berwawasan lebih luas serta mampu bersosialisasi dengan masyarakat luas dalam bidang olahraga sepakbola.
\end{abstract}

Kata Kunci: karang taruna; pelatih sepakbola 


\section{Pendahuluan}

Presiden Republik Indonesia Joko Widodo emberikan perhatian khusus pada kemajuan pesepakbolaan nasional. Serangkaian perbaikan harus segera dilakukan. Pembinaan sepak bola juga perlu dilaksanakan dari kampung dan desa. "Pemerintah akan terus memberikan perhatian untuk mempercepat pembangunan sepak bola nasional kita. Meski perlu dicatat bahwa pembinaan pada cabor yang lainnya juga akan diteruskan," kata Jokowi di Kantor Presiden, Jakarta, Selasa (24/1/2017).

Sedikitnya ada empat hal yang bisa dilakukan agar pesepakbolaan Indonesia terus berkembang dan mencapai prestasi terbaik. Pertama, pembinaan sejak usia dini. Indonesia tidak akan menghasilkan pemain terbaik bila pembinaan hanya instan dan tidak dilakukan sejak kecil. Pembenahan sistem tata kelola sepak bola nasional harus lebih kompetitif, berkualitas, dan menjunjung tinggi fair play. Kompetisi yang baik juga akan melahirkan bibit pemain yang potensial.

Pembinaan manajemen klub juga tidak bisa dilupakan. Khusus untuk pembinaan klub, masih ingin mendengar masukan dari berbagai pihak. Ketersediaan infrastruktur juga menjadi prioritas. Keberadaan stadion dan tempat latihan harus memenuhi standar. Jangan sampai lahan untuk lapangan dan stadion dialihfungsikan menjadi kawasan komersial. BUMN juga dapat berperan dalam pembinaan.

Sepakbola adalah olahraga ndeso karena yang bebas memainkannya cuma orangorang (yang tinggal di) ndeso. Mereka, orang-orang ndeso, tidak punya beban pikiran untuk patungan sewa lapangan. Mereka bebas berkejaran menendang bola sejak ayam berkokok hingga azan Maghrib berkumandang. Sepakbola adalah primadona, yang penggemarnya di mana-mana. Namun, kini konsepnya sudah berubah. Dulu, sepakbola adalah olahraga yang jamak dimainkan orang-orang; kini, sepakbola menjadi sekadar tontonan. Regenerasi merupakan hal yang selalu dianggap krusial di dalam sepakbola. Banyak insan sepakbola berbicara mengenai pembinaan usia dini tanpa tahu bagaimana mencapainya dengan cara yang efektif dan riil.

Semakin maju sepakbola suatu negara, semakin maju pula cara pandang mereka mengenai regenerasi. Negara-negara tradisi kuat di sepakbola seperti Brasil, Argentina, Belanda, Perancis, Jerman, Spanyol, Inggris, dan Italia tidak pernah kehabisan sumber daya pemain karena adanya regenerasi yang berjalan dengan baik.

Mengapa, misalnya, negara dengan populasi hanya 17 juta jiwa seperti Belanda tidak pernah kehabisan talenta sepakbola? Mengapa Italia dan Jerman tidak pernah kehabisan penjaga gawang yang superior? Mengapa Prancis tidak pernah kehabisan stok pemain-pemain berbakat di timnasnya? Pertanyaan-pertanyaan seperti ini sangat berkaitan dengan bagaimana sistem pembinaan dan penjaringan pemain muda dibangun dan dilaksanakan.

Brasil dan Argentina adalah salah dua contoh negara yang sangat tinggi pertumbuhan pesepakbola berbakatnya yang seakan-akan seperti kejadian alam, semuanya terjadi serba otomatis tanpa effort yang maksimum. Namun, sebenarnya semua itu terbangun dalam tahap-tahap yang panjang. Pencapaian itu dapat dibangun melalui partisipasi olahraga yang teroptimalisasi dengan baik. Semakin tinggi partisipasi olahraga tertentu di sebuah negara, misalnya sepakbola, maka semakin tinggi pul suplai pemain-pemain sepakbola berbakat di negara tersebut. 
Menganalogikan dengan istilah dalam dunia ekonomi, partisipasi yang signifikan akan menciptakan "pasar persaingan sempurna" di dalam "pasar pemain bola", yang nantinya akan menciptakan keluaran yang berkualitas di level tertinggi. Adalah tugas para regulator untuk meningkatkan partisipasi masyarakat di dalam olahraga (misalnya) sepakbola, dan ini semua sangat berkaitan dengan penciptaan infrastruktur-infrastruktur sepakbola yang baik dan mudah diakses oleh seluruh lapisan masyarakat.

Di Jerman, Inggris dan Prancis, beberapa infrastruktur olahraga, seperti lapangan futsal dan lapangan sepakbola adalah milik pemerintah dan aksesnya adalah tanpa biaya, alias gratis, masyarakat hanya perlu mendaftarkan diri jika ingin bermain. Kebijakan seperti ini dinilai sangat signifikan membantu peningkatan suplai pemain sepakbola/futsal yang berkualitas. Itulah mungkin salah satu alasan mengapa Prancis dan Jerman tidak pernah kehabisan pemain berbakat, karena masyarakatnya sendiri sangat gemar dan mudah untuk bermain sepakbola.

Di kota besar seperti Jakarta, di mana semakin berjalannya waktu, semakin sedikit lahan bebas, kebanyakan diisi oleh gedung-gedung bertingkat dan pusat perbelanjaan. Lalu kapan dan di mana masyarakat bermain sepakbola? Sedikit sekali akses dan jumlah lapangan yang memadai. Selanjutnya, jika masyarakat Jakarta dan kota-kota lainnya semakin sulit untuk bermain sepakbola, kapan Indonesia bermain di Piala Dunia? Negara ini memiliki lebih dari 200 penduduk, tetapi partisipasi sepakbolanya tidak mencapai presentase yang ideal. Sebagai perbandingan, Inggris memiliki populasi 53 juta jiwa, dan partisipasi sepakbola mereka adalah 2,6 juta (5\%). Dari 2,6 juta orang yang bermain sepakbola itu, terciptalah Steven Gerrard, Theo Walcott, Joe Hart dan lain-lain, yang telah tersaring melalui sistem kompetisi sepakbola yang matang. Bayangkan jika Indonesia mencapai tingkat partisipasi (\%) yang sama dengan Inggris, maka Indonesia akan menciptakan 10 juta orang yang aktif bermain sepakbola. Secara rasio sederhana jumlah nominal, seharusnya Indonesia akan mendapat saringan pemain-pemain yang lebih berkualitas, karena perbandingannya adalah 11 pemain (timnas) banding 10 juta pemain. Wow! Menciptakan pesebakbola-pesepakbola handal bukan perkara mudah. Rata-rata pemain sepakbola level top dunia bermain sepakbola sejak usia yang sangat dini. Oleh karenanya, organisasi sistem pembinaan usia muda/dini sebenarnya adalah hal yang sangat krusial.

Lionel Messi bermain sepakbola sejak usia 4 tahun, dan bergabung dengan klub sepakbola sejak usia 5 tahun. Cristiano Ronaldo bergabung dengan sebuah klub amatir sejak umur 8 tahun, Franck Ribery sejak 6 tahun, dan Ibrahimovic dari umur 6 tahun. Poin kritisnya adalah, klub-klub sepakbola yang menampung pemain-pemain belia ini memegang peranan yang sangat penting. Itulah mengapa hampir semua klub elite di Eropa memiliki tim U-8 sebagai strategi mereka mendapatkan pemain-pemain masa depan. Lalu, mengapa regulator sepakbola Indonesia begitu mengabaikan dan cenderung tidak memperhatikan eksistensi klub-klub jenjang usia dini seperti ini (SSB/Sekolah Sepak Bola)? Padahal statistik menunjukkan bahwa pemain-pemain hebat telah bergabung dan bermain dengan sebuah klub sejak umur 5-8 tahun? Dengan demikian, dapat disimpulkan bahwa permasalahan khusus yang dihadapi oleh masyarakat adalah bagaimana mewadahi bakat dari anak-anak yang memiliki kemampuan dan keterampilan pada cabang olahraga sepakbola untuk terus dikembangkan. Permasalahan tersebut menjadi 
skala prioritas yang harus dicari solusi pemecahannya bersama bagian pendahuluan, secara garis besar memuat latar belakang, perumusan masalah, tujuan kegiatan, dan kajian literatur. Penulis dituntut mengemukakan secara kuantitatif potret, profil, dan kondisi khalayak sasaran yang dilibatkan dalam kegiatan pengabdian. Dapat digambarkan pula kondisi dan potensi wilayah dari segi fisik, sosial, ekonomi, maupun lingkungan yang relevan dengan kegiatan yang dilakukan. Paparkan pula potensi yang dijadikan sebagai bahan kegiatan pengabdian kepada masyarakat. Penulis diminta merumuskan masalah secara konkrit dan jelas pada bagian ini. Jelaskan tujuan yang hendak dicapai pada kegiatan pengabdian.

Karang Taruna Jaya Pertala di Desa Cikoneng Kec. Sukahaji merupakan organisasi di tingkat Desa/Kelurahan yang merupakan wadah bagi pemuda/i agar dapat mengembangkan minat, bakat, dan potensi yang dimiliki secara positif dan mendukung pembangunan. Slogan klasik yang menyatakan "pemuda harapan bangsa" masih relevan untuk dimaknai sebagai salah potensi pendukung pembangunan, karena pemuda/i yang sedang tumbuh dan berkembang memiliki energi dan idealisme dengan semangat tinggi.

Karang Taruna bukan organisasi pengangguran, melainkan organisasi yang mewadahi pemuda/i dengan keragaman strata baik sosial maupun ekonomi, di mana di dalamnya mereka dapat menuangkan inovasi dan kreatifitasnya yang positif. Sampai saat ini Karang Taruna Jaya Pertala masih diakui sebagai bagian dari struktur organisasi pemerintahan Desa/Kelurahan, mereka berperan dan diperankan dalam proses pembangunan.

Saat ini, pemerintah Kab. Majalengka sedang menata ruang wilayah untuk pengembangan pariwisata, olahraga dan bisnis. Dalam proses pengembangan tersebut diperlukan Sumber Daya Manusia yang kompleks. Di sini terbuka peluang/kesempatan kerja bagi anggota Karang Taruna. Oleh karena itu, merupakan sebuah keharusan dimana kedua organisasi tersebut meningkatkan keterampilan anggota dan/atau kadernya dalam hal pengetahuan, pendidikan, dan keterampilan non-academic lainnya. Sesuai dengan sasaran RPJMN-III (2015-2019) tentang "Memantapkan pembangunan secara menyeluruh dengan menekankan pembangunan keunggulan kompetitif perekonomian yang berbasis pada Sumber Daya yang tersedia, Sumber Daya Manusia yang berkualitas serta kemampuan IPTEK. Akan tetapi, berdasarkan hasil pre-research diungkap bahwa, sebagian besar anggota Karang Taruna belum siap menghadapi kemajuan teknologi dalam bidang olahraga khsusnya sepakbola modern terutama mereka yang tidak mengenyam pendidikan tinggi belum memiliki keterampilan academic dan non-academic secara khusus. Salah satu keterampilan khusus yang belum dikuasai adalah keterampilan penggunaan media yang menggunakan bahasa Inggris.

Fakta di lapangan menunjukkan bahwa anggota Karang Taruna Jaya Pertala memiliki permasalahan dalam memahami dan menguasai pelatihan sepakbola secara teoritis maupun prakta dengan baik dan benar dikarenakan beberapa faktor, yaitu sebagai berikut:

1) Para anggota merasa kesulitan dalam memahami cara melatih sepakbola modern

2) Sulitnya mempelajari ilmu kepelatihan dan pembuatan program latihan sepakbola.

3) Kurangnya kesempatan untuk mengaplikasikan teori latihan

4) Tidaknya ada pelatihan/pembimbingan/pembekalan bagi anggota terutama yang tidak dipungut biaya. 
5) Minimnya sarana dan prasarana pendukung latihan.

Berdasarkan penemuan di lapangan, maka permasalahan prioritas yang dihadapi oleh anggota Karang Taruna Jaya Pertala adalah lemahnya keterampilan melatih terutama ketika dihadapkan pada kondisi dilapangan. Oleh sebab itu, Tim PKM dan organisasi tersebut sepakat mengenai harus adanya solusi atau penyelesaian atas permasalahan yang dihadapi.

Adapun kegiatan yang akan dilakukan berupa pelaksanaan pelatihan sepakbola. Manfaat dari kegiatan pelatihan ini diharapkan anggota Karang Taruna Jaya Pertala dapat menguasai cara berkomunikasi dan melatih sesuai konteks secara baik dan benar sehingga akan membuat mereka menjadi pelatih, mampu menjadi pelaku aktif dan tidak akan termarginalkan. Pada akhirnya, peran mereka secara tidak langsung akan mendukung program pemerintah daerah dengan meningkatnya prestasi dalam bidang olahraga khususnya sepakbola.

Dalam hal ini, para pemuda anggota Karang Taruna Jaya Pertala diharapkan menjadi pelopor dan diharapkan mampu berperan di bidang ini. Dalam hal ini, anggota Karang Taruna Jaya Pertala yang menyebar di berbagai bidang pekerjaan akan berperan sebagai pemberi layanan kepada anak-anak yang menginginkan adanya pelatih sepakbola yang berkomepeten.

Terampil melatih dalam sesuai konteks (real context) dapat menjadi modal utama anggota Karang Taruna Jaya Pertala yang terdiri dari pemuda-pemudi produktif dalam bersaing mendapatkan pekerjaan baik sebagai pelatih, pembina, assisten pelatih, dll. Terlebih lagi, keterampilan melatih dapat membekali mereka menjadi pribadi yang lebih berwawasan luas serta mampu bersosialisasi dengan masyarakat.

\section{Metode}

Secara empiris, anggota Karang Taruna Jaya Pertala sebagai peserta pelatihan sudah masuk kategori orang dewasa. Maka, dalam kegiatan pembelajaran diperlukan pemilihan metode atau cara yang tepat, agar suasana belajar kondusif dan tidak membosankan. Secara teoritis, metode paling cocok untuk peserta latihan dari kalangan ini adalah metode andragogi atau seni dan pengetahuan membelajarkan orang dewasa (Kamil dalam Ibrahim: 2007), dalam prakteknya akan menekankan pada kegiatan pembelajaran tentang materi yang memang mereka butuhkan. Kegiatan PKM ini diharapkan dapat membantu masyarakat memecahkan masalah yang dihadapi, sehingga hasilnya dapat langsung dikenakan kepada masyarakat yang bersangkutan (Arikunto, 2002), maka kegiatan PKM ini pun menggunakan pendekatan Action Research atau participatory research. Dengan demikian, tim PKM menawarkan kepada mitra, pelaksanaan kegiatan pelatihan sepakbola. Alasan empiris yang diajukan adalah kondisi aktual yang dihadapi mereka. Dalam hal ini, Pemerintah Kabupaten Majalengka sendiri sedang giat merancang dan menata system keolahragaan sampai tingkat pedesaan. Berikut diagram alur kegiatan PKM. 


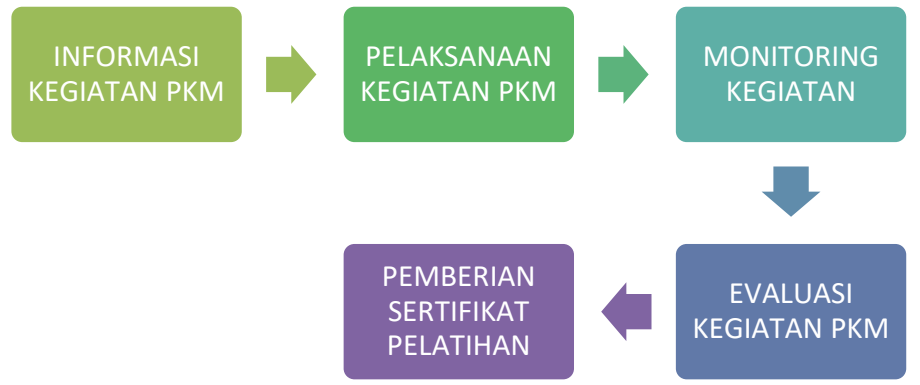

\section{Tahapan Pelaksanaan}

1. Menginformasikan kegiatan PKM kepada kelompok mitra serta melakukan komunikasi dan koordinasi dengan pengelola (pimpinan) untuk memperoleh data tentang jumlah peserta yang akan mengikuti kegiatan pelatihan, sehingga jadwal dan pola pelatihan dapat disesuaikan dengan jumlah peserta.

2. Melaksanakan kegiatan pelatihan sepakbola sebanyak 6 (enam) kali pertemuan.

a. Penjelasan mengenai istilah-istilah kepelatihan dalam cabang sepakbola. Kegiatan dilakukan dengan mengundang pakar kepelatihan cabang sepakbola dari Pengda dan Pengcab PSSI.

b. Penjelasan mengenai perbedaan melatih untuk beberapa kategori usia diberikan oleh TIM PKM dengan memutar video yang menggambarkan perbedaan melatih di beberapa negara.

c. Latihan dengan memakai istilah-istilah dalam pelatihan sepakbola oleh TIM PKM. Metode yang digunakan Role Play, Games, Talking Box, dll.

d. Latihan praktek langsung dilaksanakan selama 12 hari pelatihan.

e. Evalusi dan tes langsung dengan TIM PKM.

3. Setiap pertemuan, peserta diarahkan untuk selalu aktif dan komunikatif. Setiap akhir pertemuan peserta akan dievaluasi dengan diberi soal tes. Tes yang digunakan lebih menitikberatkan pada ilmu kepelatihan cabang sepakbola. Sehingga kemampuan dan pemahaman komunikasi mereka akan terukur. Diakhir pelatihan, peserta juga akan dievaluasi kembali tentang semua materi yang pernah diberikan.

4. Setelah kegiatan berakhir, peserta akan diberi sertifikat pelatihan.

Partisipasi Mitra dalam Pelaksanaan Program PKM

Dalam hal partisipasi mitra, sejak Tim PKM melakukan survey dengan melakukan kunjungan awal ke lokasi, pihak mitra menyambut dengan gembira dan penuh harap. Ketika rencana dikemukakan, mitra menerima dengan penuh antuias, karena mereka benar-benar membutuhkan. Mereka paham betul tentang fenomena yang terjadi, rencana pemerintah yang akan meningkatkan prestasi olahraga khususnya cabang sepakbola dengan segala konsekuensinya. Mitra tidak ingin menjadi penonton, mereka ingin menjadi subjek dan ikut terlibat dalam perubahan social yang akan terjadi sebagai dampak instruksi pemerintah tersebut. Maka, mempersiapkan diri dengan belajar ilmu kepelatihan merupakan salah satu solusi cerdas.

Sebagai bentuk partisipasi yang nyata, mitra bersedia memberikan informasi yang dibutuhkan Tim PKM, baik secara lisan maupun tulisan. Selanjutnya, kedua mitra telah menyatakan kesediaanya menyediakan tempat dan waktu untuk melaksanakan 
kegiatan pelatihan sepakbola. Selain itu mitra juga berkontribusi dalam proses kegiatan sebagai peserta pelatihan.

Evaluasi Pelaksanaan Program dan Keberlanjutan Program

Untuk mengawal Program Kemitraan Masyarakat ini, maka Tim melakukan tahapantahapan evaluasi sebagai berikut:

Tabel 1. Tahapan Evaluasi

\begin{tabular}{|c|c|c|}
\hline NO & Langkah-langkah Evaluasi & Teknik Penilaian \\
\hline \multicolumn{3}{|c|}{ Setelah PKM } \\
\hline 1 & $\begin{array}{l}\text { Melakukan monitoring pada kelompok mitra } \\
\text { setelah program selesai (peningkatan } \\
\text { kemampuan melatih) }\end{array}$ & Wawancara \\
\hline 2 & Mengevaluasi pemahaman teori latihan & Wawancara, kuisinoer \\
\hline \multicolumn{3}{|c|}{ Keberlanjutan } \\
\hline 1 & Sports Day & Observasi ke mitra \\
\hline 2 & Pemberdayaan SDM dan Sapras & Observasi ke mitra \\
\hline 3 & Pembuatan dan pemakaian modul & Observasi ke mitra \\
\hline 4 & Pembuataan program latihan & Observasi ke mitra \\
\hline 5 & Peningkatan daya saing & Observasi dan wawancara \\
\hline 6 & Pemerolehan lapangan kerja & Observasi dan wawancara \\
\hline 7 & Peningkatakan mata pencaharian & Observasi dan wawancara \\
\hline
\end{tabular}

Dan keberlanjutan dari program ini, masyarakat khususnya karang taruna menjadikan program pelatihan pelatih menjadi program desa untuk tahun-tahun selanjutnya.

\section{Hasil dan Pembahasan}

Pengabdian kepada masyarakat adalah usaha untuk menyebarluaskan ilmu pengetahuan, teknologi, dan seni kepada masyarakat. Kegiatan tersebut harus mampu memberikan suatu nilai tambah bagi masyarakat, baik dalam kegiatan ekonomi, kebijakan, dan perubahan perilaku (sosial). Uraikan bahwa kegiatan pengabdian telah mampu memberi perubahan bagi individu/masyarakat maupun institusi baik jangka pendek maupun jangka panjang.

Solusi yang ditawarkan untuk menyelesaikan permasalahan prioritas yang dihadapi mitra:

1. Masalah: Para anggota merasa kesulitan dalam memahami cara melatih sepakbola modern.

Solusi: pelatihan sepakbola dengan metode yang menyenangkan. Materi akan ditulis dalam modul pelatihan. Pembelajaran menggunakan bantuan media audio-visual.

2. Masalah: Sulitnya mempelajari ilmu kepelatihan dan pembuatan program latihan sepakbola

Solusi: proses pembelajaran tidak akan fokus pada melatih teknik atau fisik. Akan tetapi bagaimana seorang pelatih mampu membuat program latihan. Peserta akan sering berlatih pembuatan program latihan.

3. Masalah: Kurangnya kesempatan untuk mengaplikasikan teori latihan 
Solusi: menciptakan lingkungan latihan yang aktif dan kebiasaan berbicara. Setiap pertemuan akan selalu ada role play guna melatih mitra dalam mengaplikasikan ilmu melatih sepakbola yang sudah didapat.

4. Masalah: Tidaknya ada pelatihan/pembimbingan/pembekalan bagi anggota terutama yang tidak dipungut biaya.

Solusi: menyediakan dan menyelenggarakan pelatihan sepakbola tanpa menarik biaya dari peserta.

5. Masalah: Minimnya sarana dan prasarana pendukung latihan.

Solusi: membiasakan penggunaan ilmu kepelatihan dalam proses latihan.

\section{Kesimpulan}

Berdasarkan hasil pengabdian dapat disimpulkan sebagai berikut: Dari pelatihan sepakbola ini berupa kemampuan anggota mitra yang bertambah fasih sehingga mereka dapat menggunakan ilmu melatih dengan baik dan benar dalam berkomunikasi. Peserta pelatihan terbiasa dan dapat meningkatkan keterampilan pembuatan program latihan sesuai kebutuhan dan jenjang usia. Terciptanya kebiasaan menggunakan ilmu melatih sehingga ada kesempatan bagi peserta mengaplikasikan pengetahuannya. Meningkatnya motivasi dan keinginan anggota mitra untuk mempelajari teori latihan sepakbola demi menambah keterampilan dan daya saing. Peserta dapat meningkatkan keterampilan dalam melatih

\section{Daftar Pustaka}

Arikunto, S. (2002). Prosedur Penelitian Sutau Pendekatan Praktek. Jakarta: Rineka Cipta

Badan Pusat Statistik Kab. Majalengka. (2014)

Badriah, Dewi Laelatul. (2012). Metodologi Penelitian Ilmu-Ilmu Kesehatan. Bandung: Multazam

FIFA. (2009). Laws Of The Game. PSSI

Halliday, M.A.K. (1985). An Introduction to Functional Grammar London: Edward Arnold

Ibrahim, R. (2007). Ilmu dan Aplikasi Pendidikan. Bandung: Imperial Bhakti Utama

Kemendikbud. (2015). Rencana Strategis Kementerian Pendidikan dan Kebudayaan 20152019. Jakarta: Kemendikbud

Luxbacher, Joe.(2004). SEPAKBOLA: Taktik dan Teknik Bermain. Jakarta: PT Raja Grafindo Persada

Nurhasan. (2007). Tes dan pengukuran keolahragaan. Bandung: Jurusan Pendidikan Kepelatihan Fakultas Olahraga dan Kesehatan Universitas Pendidikan Indonesia

PSSI.(2010). Peraturan Organisasi Tentang Sistem Pembinaan dan Pengelolaan Perangkat Pertandingan. Tidak diterbitkan

RPJMD Kab. Majalengka 2014-2018

RPJMN-III. 2015-2019

Scheunemann, Timo.(2012). Kurikulum dan Pedoman Dasar Sepak Bola Indonesia. Jakarta: Tidak diterbitkan 
Sugiyono. 2010. Metode Penelitian Pendidikan. Bandung: Alfabeta

Sugiyono, (2013). Metode Penelitian Pendidikan, Pendekatan Kuantitatif Kualitatif dan R\&D.. Bandung. ALFABETA. 